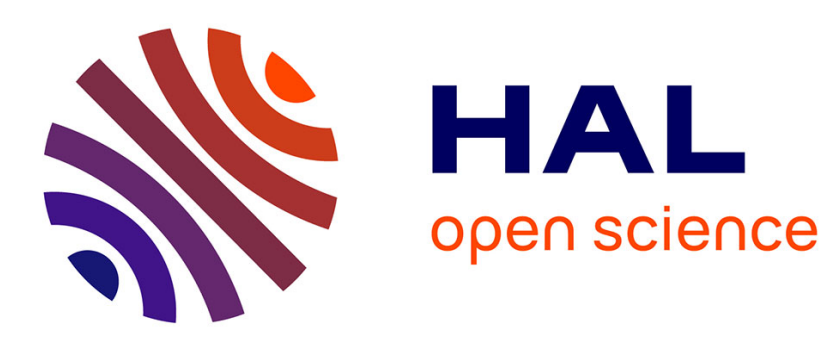

\title{
Thermo-Mechanical Fractionation of Green Biomass
}

Marion Blanc, Patricia Arlabosse

\section{To cite this version:}

Marion Blanc, Patricia Arlabosse. Thermo-Mechanical Fractionation of Green Biomass. Drying Technology, 2013, 31 (4), pp.462-469. 10.1080/07373937.2012.740544 . hal-01165198

\section{HAL Id: hal-01165198 \\ https://imt-mines-albi.hal.science/hal-01165198}

Submitted on 18 Jun 2015

HAL is a multi-disciplinary open access archive for the deposit and dissemination of scientific research documents, whether they are published or not. The documents may come from teaching and research institutions in France or abroad, or from public or private research centers.
L'archive ouverte pluridisciplinaire HAL, est destinée au dépôt et à la diffusion de documents scientifiques de niveau recherche, publiés ou non, émanant des établissements d'enseignement et de recherche français ou étrangers, des laboratoires publics ou privés. 


\title{
THERMO-MECHANICAL FRACTIONATION OF GREEN BIOMASS
}

\section{Blanc and P. Arlabosse}

\author{
Université de Toulouse ; Mines Albi ; CNRS; Centre RAPSODEE, Campus Jarlard, \\ F-81013 Albi cedex 09, France
}

\author{
Corresponding author: Patricia.Arlabosse@mines-albi.fr, \\ tel: +33 5634932 37, fax: +33563493243
}

\begin{abstract}
Green biomass can efficiently be separated into a fiber rich fraction and a green juice with the TAMD process. This process combines a mechanical pressing and a moderate heating of the walls of the apparatus. This work aims to investigate the influence of the biomass water potential on the kinetic and to identify the optimal processing conditions. If the TAMD process is used as a pre-treatment for fodder dewatering, $70^{\circ} \mathrm{C}$ and $300 \mathrm{kPa}$ are the optimum conditions to reach a high separation yield (+25.5\% compared to current processes) in short times. For biorefining purpose, a lower wall temperature is required.
\end{abstract}

Key words: Dewatering, Process Intensification, Alfalfa, Water Potential, Extraction Yield 


\section{Introduction}

As the ruminant livestock sector becomes less attractive to farmers and much of the lands under grass are unsuitable for alternative arable use, a surplus of grassland biomass is predicted in many regions of Europe [1,2]. Green biorefineries (GBR) were identified as potential sustainable tools for processing these 'nature-wet' raw materials. GBR focus on valuable intermediates or end-products, derived from the processing of a fiber-free extract containing the protoplasmic fluid - the green juice - or a fiber-rich solid fraction - the press cake. Among the most promising derivative products from the green juice, let us quote speciality feeds for pigs and hens recovered from the green protein phase [3, 4], white proteins for foams, foam stabilizer or films recovered from the soluble protein phase [5], aminium lactate produced by fermentation of the deproteinizied green juice [6], polylactic acid [7] or even heat and power [8] coming from lactic acid and water soluble extracts used as raw material in a fermentation process. Fibres are usable as foodstuff for animals $[9,10]$ but can also be used as blow-in insulation products and insulation boards [11], as materials (pots and mulch boards) used in horticulture [12] or as combustion pellets [8, 11]. Several biorefining initiatives are reported or scheduled in many European countries [2, 5, 13, 14] while techno-economic studies aim to establish the conditions of profitability of GBR systems $[5,12,15]$.

Mechanical fractionation is usually the first unit operation in a green biorefinery plant. So far, green juice extraction involves mechanical pulping to disintegrate the cell walls followed by pressing [16], possibly with multistage addition of water and expression following the first pressing [17]. Refiner and screw press are usually used. Successful separation with an extruder press is also reported [18]. Between 40 and $60 \%$ of the total available water, $50 \%$ of 
the total amount of lactic acid and $23 \%$ of the total available amount of proteins go into the press juice while $95 \%$ of the total available fibers are recovered in the press cake $[16,18,19]$. Higher water separation yield can be achieved through process intensification. Intensification of mechanical dewatering can take several forms: simultaneous application of an electric field $[20,21,22,23]$, superimposition of ultrasounds [24, 25] or with heat supply. Combination of pressure and temperature can be envisaged during the filtration stage only (if any), the expression stage only, during both regimes, as a pre- or a post-treatment $[26,27,28,29,30$, 31]. Various processes were experimented at lab and pilot scales for paste-like products, like sewage sludge, and biomaterials, like lignite and bagasse. But, most of the time, the operating conditions lead to a vaporization of the solvent. For instance, the Mechanical Thermal Expression (MTE) process, first investigated in the mid 1990s by Strauss and coworkers [27, 28] and recently extended by Hoadley and coworkers in Monash University [30, 32], comprises a preheating step prior to filtration and consolidation in its current design. The processing temperature is set above the normal boiling point of the water. To prevent evaporation, the process is held under a sufficient back pressure. Consequently, upon exposure to atmospheric pressure, a flash evaporation occurs and contributes to further moisture reduction. The main part of the moisture reduction was attributed to the collapse of the internal material porosity $[33,34]$. If thermal mechanical dewatering method is not a brand new technology, the operating conditions of the thermally assisted mechanical dewatering (TAMD) process [35] and its use for the mechanical fractionation of the herbaceous biomass [36, 37] are quite innovating. The TAMD process operates at low pressure (usually $300 \mathrm{kPa}$ ) with a moderate heating of the press walls $\left(\mathrm{T}_{\text {wall }} \leq 80^{\circ} \mathrm{C}\right)$. The TAMD process proved to be especially efficient for green biomass. For instance, up to $83 \%$ of the inherent liquid fraction can be removed from alfalfa. The energy consumption of thermally assisted mechanical dewatering processes ranged from 5 to $30 \%$ of the latent heat 
of vaporization depending on the operating conditions and the biomass [30, 36, 38]. For alfalfa dehydration, the energy consumption of the TAMD process was assessed to $205 \mathrm{~kJ} / \mathrm{kg}$ of the recovered juice, that is to say $8.5 \%$ of the latent heat of vaporization of water [36]. In a great number of countries, thermal drying of the fresh or pre-wilted fodder is an alternative method of forage conservation. Even for pre-wilted fodder, the main weakness of this industry is the high energy consumption of the dryers, inducing high production costs (compared to soya production costs for instance) but also high carbon footprint. The inherent energy requirement for drying is thus significantly reduced $(-46 \%)$ when the feed is dewatered with the TAMD process [39], thanks to the increase of the dry solid content of the feed at the dryer inlet. In addition, implementation of the TAMD process prior to drying could contribute to turn existing dried fodder processing plants into biorefineries, diversifying the alfalfa products and increasing the sales turnover. So far, mechanical pressing is only used to extract the juice for poultry feeding in a few alfalfa drying factories.

The dehydration yield depends mainly on the processing temperature [36] while the kinetic depends on the processing temperature and sometimes on the applied pressure [40]. Especially, at low processing temperature $\left(\mathrm{T}_{\text {wall }}<70^{\circ} \mathrm{C}\right)$, the processing pressure has a crucial influence on the moment when the juice begins to flow out. The latency time seems to be correlated with the hydric status of the plant: the driest the biomass, the longer is the waiting period. For the transition from batch to continuous processing, the interaction between the plant water status and the processing conditions needs to be clarified. The present study aims (1) to clarify the role of the plant water status on the juice extraction kinetics, (2) to suggest some dewatering mechanisms and (3) to identify the optimal processing conditions for dewatering purpose and/or for biorefining purpose. After a description of the experimental device and analytical protocols, the influence of the processing conditions on the dewatering 
kinetics, the water extraction yield and the green juice composition are analyzed in section 3. Finally, the optimal conditions for dewatering and biorefining purposes are given as concluding remarks.

\section{Materials and methods}

\subsection{Thermally assisted mechanical dewatering press}

At the laboratory scale, the TAMD process consists of a compression cell inserted CARVER $^{\circledR}$ hydraulic press (Carver Inc., Wabash, United State), which has a maximum pressing capacity of $14800 \mathrm{kPa}$ and provides the pressure required to progress a downward expression. The cell (Figure 1) includes a compressive piston, a hollowed cylindrical vessel, a filter medium and a collector. The compression chamber has a diameter of $148 \mathrm{~mm}$ and a maximum height of $60 \mathrm{~mm}$. In spite of its low mechanical resistance, Teflon ${ }^{\mathrm{TM}}$ was selected as constitutive material of the vessel walls to minimize the frictions with the piston. Consequently, a stainless steel external jacket is added to ensure the mechanical resistance of the unit. The cell is fitted with a planar metal medium, with square pores of side $300 \mu \mathrm{m}$. To investigate the influence of a heat supply, three electric resistances are inserted in the upper part of the compressive piston, made of copper to reduce thermal inertia. Each resistor can supply up to $350 \mathrm{~W}$. A temperature sensor, set in the piston, is used for the temperature regulation of the copper block. The accuracy of the sensor with its acquisition line is estimated at $\pm 0.03^{\circ} \mathrm{C}$. 

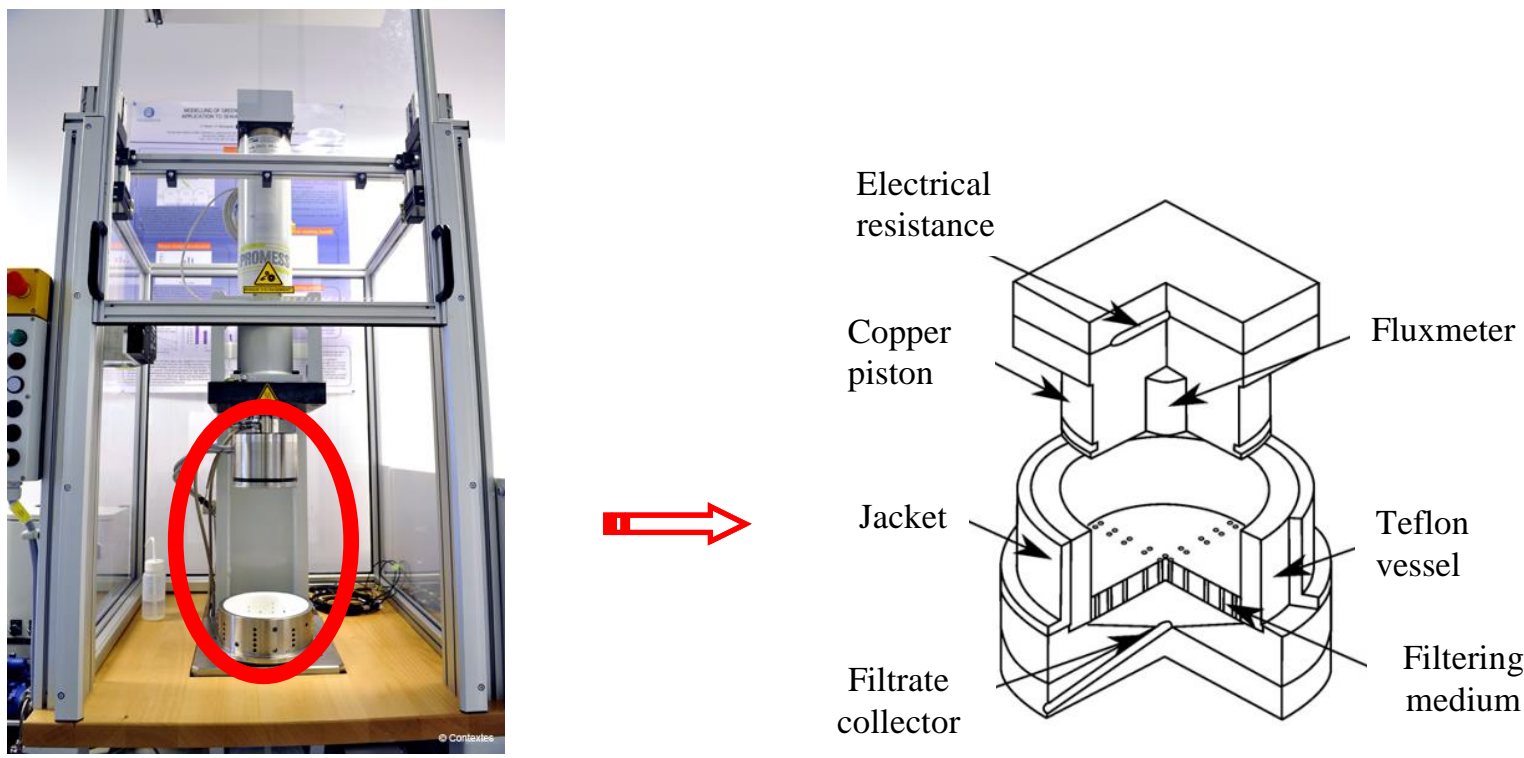

Figure 1 - TAMD process

\subsection{Feed material and TAMD procedure}

Alfalfa, also known as Lucerne in Europe, was selected as raw material for the present study. With a dedicated area of about 30 million hectares worldwide and an estimated annual production [41] of 436 million tons, alfalfa is the major forage crop in temperate regions. Indeed, this perennial legume, in the pea family Fabaceae, has the highest feeding value of all common hay crops, with high protein content and highly digestible fiber. Fresh alfalfa (Medicago sativa L.) was field-chopped manually. Samples were taken at weekly intervals between mid-May and mid-June. The fresh alfalfa was immediately transported to the laboratory and stored at $4{ }^{\circ} \mathrm{C}$ in a tight container within $1 \mathrm{~h}$ after the harvest. Dewatering experiments were carried out in the two days following the harvest.

The mechanical fractionation protocol was as follows. About $200 \mathrm{~g}$ of fresh alfalfa were chopped into $5-\mathrm{cm}$ pieces and introduced at room temperature into the TAMD device. At $\mathrm{t}=0$, a constant pressure was applied through the compressive piston, previously heated at the selected operating temperature $\left(30,50\right.$ or $\left.70^{\circ} \mathrm{C}\right)$. The biomass was progressively separated 
into a green juice and a press cake. The filtrate recovered in the collector flowed out into a container laid on the computer interfaced balance. The mass of filtrate was recorded at set time intervals of $1 \mathrm{~s}$. At the end of the experiment, the press cake was weighed. Traditionally, juice extraction involves mechanical pulping followed by pressing. To assess the performances of the TAMD process, some samples were macerated in a blender and dewatered at $300 \mathrm{kPa}$ and ambient temperature. In the following, 'Pulp' will indicate the minced alfalfa while 'Raw' will refer to the chopped alfalfa.

\subsection{Plant water status characterization}

Oven-drying at $105^{\circ} \mathrm{C}$ for $24 \mathrm{~h}$ is used for the determination of the dry basis moisture content, W. According to literature [42], moisture content often fails as an indicator of the plant water status and the concept of water potential, $\psi_{w}$, has proven to be more useful in understanding water movement in plants. Plant cell consists of a gel-like substance, called the protoplasm, bounded on the outside by the plasmalemma, a selectively permeable membrane, and the cell wall. Difference in solute concentrations across the plasmalemma (generally a dilute solution on the outside and a concentrated solution on the inside) causes net flow of water toward the side with lower water concentration. $\psi_{w}$, expressed in $\mathrm{Pa}$, is thermodynamically defined according to equation (3):

$$
\psi_{w}=\frac{\mu_{w}-\mu_{0}}{\bar{V}_{w}}
$$

where $\mu_{w}$ is the chemical potential of water in the solution $(\mathrm{kJ} / \mathrm{mol}), \mu_{0}$ the chemical potential of pure water at the same temperature $(\mathrm{kJ} / \mathrm{mol})$ and $\bar{V}_{w}$ is the partial molar volume of water $\left(\mathrm{m}^{3} / \mathrm{mol}\right)$.

Rather than the thermodynamic definition, the following relation is usually preferred: 


$$
\psi_{w}=\psi_{s}+\psi_{p}+\psi_{m}+\psi_{g}
$$

Where:

$\checkmark \quad \psi_{s}$, called the osmotic potential, represents the effect of all dissolved molecules (as long as they do not precipitate);

$\checkmark \quad \psi_{p}$, the pressure potential or turgor pressure, takes into account the effects of all external pressures build up in the cell liquid thanks to the walls (usually positive in a living plant);

$\checkmark$ surface effects resulting from the interaction between water and porous solids are included in $\psi_{m}$, called the matrix potential;

$\checkmark$ and $\psi_{g}$ represents gravity effects. It can be neglected as long as plant heights are lower than $1 \mathrm{~m}$.

Usually, $\psi_{s}$ and $\psi_{m}$ are negative and $\psi_{p}$ does not compensate them so that water in plants generally has a negative $\psi_{w}$. Increasing solute concentration lowers the water potential while applying an external pressure above atmospheric or hydrating the wall matrix increases $\psi_{w}$. $\psi_{w}$ determines the direction of water exchanges when a water potential difference exists between the two sides of the plasmalemma: water runs out towards more negative $\psi_{w}$.

Pressure chambers are the most widely used tools for measuring $\psi_{w}$. Excising a leaf opens the xylem to the atmosphere. As a result, the xylem solution retracts to cross walls where sufficiently small pores exist to prevent solution from retracting farther. Pressurizing the tissue increases the water potential and forces water to return to its initial position. Pressure chambers are based on this concept [43]. A leaf is sealed into the top of the chamber, in such 
a way that a small amount of the xylem extends outside through the top (Figure 2). Gas is introduced into the chamber, increasing the pressure in the chamber and uniformly pressurizing the tissue. This raises the protoplasm water potential above that of the xylem and water flows inside the xylem. At equilibrium, when the xylem solution forms a stationary flat film without any excess on the cut surface, the pressure of the gas $\left(\mathrm{P}_{\text {gas }}\right)$ counteracts the tension exerted on the xylem solution. The xylem being part of the apoplast formed by the continuum of cell walls of adjacent cells as well as the extracellular spaces, the negative of $\mathrm{P}_{\mathrm{gas}}$ is thus a measure of the apoplast matrix potential, $\psi_{m}(a)$ :

$$
\psi_{m}(a)=-P_{g a s}
$$

In the apoplast, $\psi_{p}$ can be ignored. The water potential is thus reduced to:

$$
\psi_{w}(a)=\psi_{s}(a)+\psi_{m}(a)
$$

Now, if we admit that the osmotic potential of the xylem is low and negligible, the gas pressure is appreciably equal to the water potential of the apoplast [44]. Finally, the water potential in the apoplast being almost always the same as in each protoplasm, the water potential of the tissue is given by the negative of the gas pressure:

$$
\psi_{w}(a)=\psi_{w}(p)-P_{g a s}
$$

The more dehydrated the tissue, the more pressure is required.

Measurements of the water potential were performed with a conventional pressure chamber (Sols Mesure, Elancourt, France). The plant water status is measured within the hour following the picking up at the field. In order to prevent any evolution of the water potential, the alfalfa is bagged into a hermetic and opaque container. The tip of the stem is cut as straight as possible with a sharp blade to make the observation easier. Young alfalfa stems are 
rather soft. When sealed into the chamber, the highly flexible stem of alfalfa automatically releases some water at the cut surface. This first exhaust of water is eliminated by absorption with a tissue. Then, nitrogen is introduced in the pressure chamber. The precision of the measure is also highly depending on the nitrogen bottle outlet pressure. If this latter is set high from the beginning, the rate will be out of control in the chamber and the water potential might be exceeded. The recommended experimental procedure is to increase the pressure little by little and to wait about $15 \mathrm{~s}$ between two pressure increments so as to make sure not to overestimate the value. This technique is not expected to give an accurate value but rather an average of the whole sample. For a given alfalfa batch, at least five different samples were measured each time.

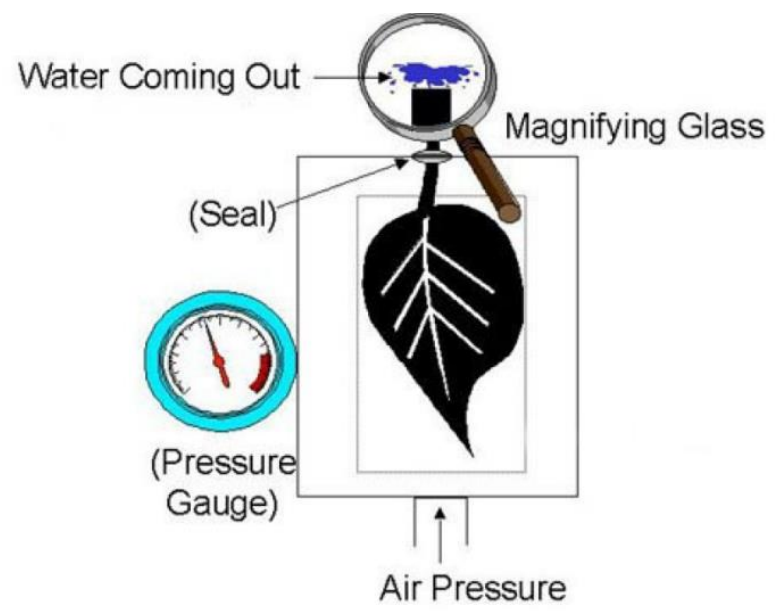

Figure 2 - Pressure Chamber

\subsubsection{Total nitrogen and crude protein of the green juice}

As pressing generates a nitrogen-rich liquid fraction, likely to be processed in a biorefinery plant or requiring to be treated before being discharged in the environment, the total nitrogen in the green juice has been analyzed with a TNM-1 unit for TOC- $V_{C S H}$ instrument (Shimadzu, Marne La Vallée, France). The juice was kept in a fridge if the analyze was carried out during the day or frozen to be analyzed later. Two replicates at least are made for 
each measure. A factor of 6.25 is used to convert the total nitrogen into crude protein $(\mathrm{CP})$. Consequently, crude protein includes both true protein and non-protein nitrogen.

\subsubsection{Cell structure}

The plant tissues were fixed with $2.5 \%$ glutaraldehyde $(25 \%)$ in a $0.05 \mathrm{M}$ sodium-cacodylate buffer for an hour. After rinsing and ambient-air drying, the samples were cut into $30 \mu \mathrm{m}-$ thick sections with a microtome Microm HM 255 (Thermo Scientific, Saint Herblain, France). Observations were then carried out thanks to the optic microscope LEICA DMRB whose magnifying power goes from x 100 to x630.

\section{Results and discussion}

Alfalfa batches were sampled during three consecutive weeks (June $8^{\text {th }}$, June $15^{\text {th }}$ and June $\left.21^{\text {st }}\right)$. This corresponds to the first regrowth period after the first agricultural harvest. Because of the weather conditions, the three batches appreciably have different moisture contents and water potentials (Table 1). And, as can be seen on Table 1, these two physical properties are not correlated.

\begin{tabular}{|c|c|c|}
\cline { 2 - 3 } \multicolumn{1}{c|}{} & $\begin{array}{c}\mathrm{W} \\
(\mathrm{d} . \mathrm{b})\end{array}$ & $\begin{array}{c}|\Psi \mathrm{w}| \\
(\mathrm{kPa})\end{array}$ \\
\hline 8 June & 4.71 & $850 \pm 50$ \\
\hline 15 June & 4.46 & $350 \pm 50$ \\
\hline 21 June & 3.93 & $600 \pm 100$ \\
\hline
\end{tabular}

Table 1 - Initial moisture content and water potential of the alfalfa samples

The dewatering kinetics were investigated for two wall temperatures, 30 and $50^{\circ} \mathrm{C}$, and three processing pressures, 300, 500 and $1000 \mathrm{kPa}$. The results achieved with alfalfa sampled on 
June $8^{\text {th }}$ are described in details in the following. For a wall temperature set at $30^{\circ} \mathrm{C}$ (Figure 3), no water is removed from the press cake as long as the applied pressure remains significantly lower than the water potential. When the applied pressure exceeds the water potential, water runs out almost immediately. For the intermediate pressure $\left(\mathrm{P}_{\text {applied }}=500\right.$ $\mathrm{kPa}$ ), six minutes are required before a small amount of juice flows out of the press cake. In the plant, water moves down a water potential gradient, from root to leaf. As a result, water potential in growing tissues is less than the one in the mature tissues located in the bottom part of the plant. Fulfilling a representative sampling is thus rather difficult and the five measurements performed give only an order of magnitude of the average water potential. The water potential of some leaves was probably lower than the applied pressure of $500 \mathrm{kPa}$, what would explain the partial dewatering.

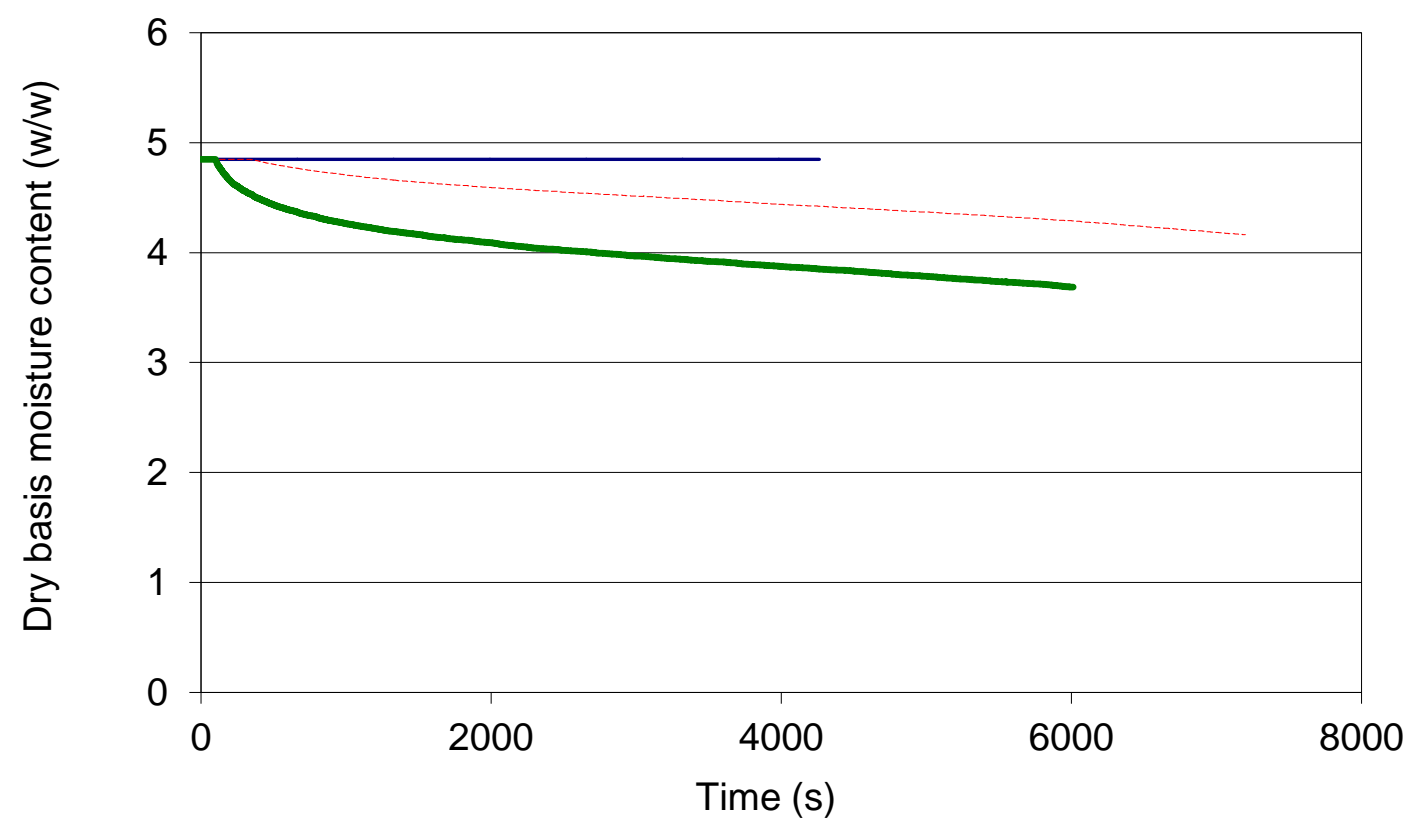

Figure 3 - Influence of the processing conditions on the dewatering kinetics for $\psi_{\mathrm{w}}=850 \mathrm{kPa}$ : $\mathrm{T}_{\text {wall }}=30^{\circ} \mathrm{C}$ and $\mathrm{P}_{\text {applied }}=300 \mathrm{kPa}(-), \mathrm{P}_{\text {applied }}=500 \mathrm{kPa}(--), \mathrm{P}_{\text {applied }}=1000 \mathrm{kPa}(-)$

Cell to cell mass transport through the symplasm, the cytoplasmic continuum created by the plasmodesmata, is the main pathways for alfalfa mechanical dewatering, as can be seen on 
Figure 4. Applying an external pressure increases the protoplasm water potential above that of the xylem and water flows inside the xylem. Since the plasmalemma is water permeable, the juice extruded from the cut end of the stem is almost pure water. Consequently, the solute concentration in the cells near the xylem increases and the water potential decreases. A water potential gradient appears locally, inducing a water movement by osmosis from the adjacent turgid cells towards those partially dehydrated or plasmolyzed.

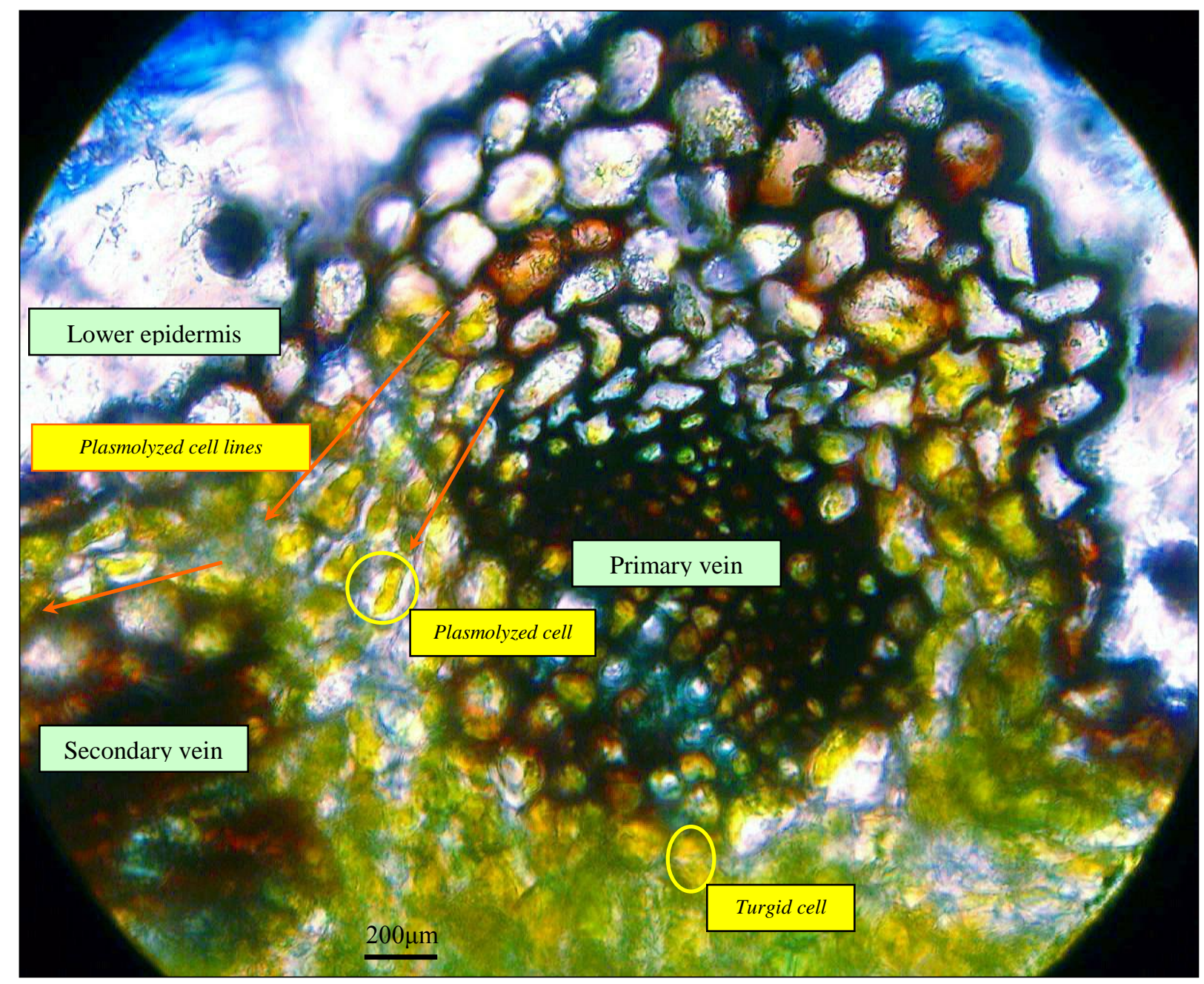

Figure 4 - Photograph of the vegetable cells after fractionation in the TAMD process

In the absence of any preliminary trituration of the biomass, which would aim at splitting the cell walls to recover hydrophobic proteins bound to the cell walls, this mechanism explains the low CP concentration of the green juice produced with chopped alfalfa (referred as 'Raw' 
in Table 2). For the minced alfalfa (referred as 'Pulp' in Table 2), the shearing induced by the blender breaks the cellular walls and releases parietal proteins, enhancing significantly the $\mathrm{CP}$ content of the green juice.

\begin{tabular}{|c|l|c|c|}
\cline { 3 - 4 } \multicolumn{2}{c|}{} & \multicolumn{2}{c|}{$\mathrm{CP}(\mathrm{g} / \mathrm{L})$} \\
\hline \multirow{3}{*}{$30^{\circ} \mathrm{C}$} & Raw, $\mathrm{P}=300 \mathrm{kPa}$ & - & - \\
\cline { 2 - 4 } & $\mathrm{Pulp}, \mathrm{P}=300 \mathrm{kPa}$ & $\mathbf{2 5 . 5}$ & 0.17 \\
\cline { 2 - 4 } & Raw, $\mathrm{P}=500 \mathrm{kPa}$ & $\mathbf{4 . 9 2}$ & 0.02 \\
\cline { 2 - 4 } & Raw, $\mathrm{P}=1 \mathrm{MPa}$ & $\mathbf{4 . 5 1}$ & 0.03 \\
\hline \multirow{3}{*}{$50^{\circ} \mathrm{C}$} & Raw, $\mathrm{P}=300 \mathrm{kPa}$ & $\mathbf{1 2 . 6 9}$ & 0.04 \\
\cline { 2 - 4 } & Raw, $\mathrm{P}=500 \mathrm{kPa}$ & $\mathbf{1 2 . 5 2}$ & 0.11 \\
\cline { 2 - 4 } & Raw, $\mathrm{P}=1 \mathrm{MPa}$ & $\mathbf{1 0}$ & 0.09 \\
\hline $70^{\circ} \mathrm{C}$ & Raw, $\mathrm{P}=300 \mathrm{kPa}$ & $\mathbf{9 . 9 8}$ & 0.13 \\
\hline
\end{tabular}

Table 2 - Influence of the processing conditions on the crude protein content in the juice (median value in bold and standard deviation in italic).

For a wall temperature set at $50^{\circ} \mathrm{C}$ (Figure 5), the flow is like previously immediate if the applied pressure exceeds the water potential. When the applied pressure is lower, a latency period appears. The period is all the more long as the applied pressure is low. An increase in the applied pressure results in a decrease of the press cake macro-porosity and thus an enhancement of the diffusive heat transfer. The rise in temperature of the press cake is faster when a higher stress is applied on the press cake. This induces an increase of the osmotic pressure, conventionally calculated with the van't Hoff equation [42] and enhances mass transfer. Of course, the final moisture content is independent of the pressure applied (asymptotic behavior for long times). Furthermore, phospholipids constituting the membrane become more fluid as temperature increases. This affects the permeability of the cell membrane, allowing substances, that wouldn't usually do so, to leave the cell more easily. Thus, without any preliminary maceration, the $\mathrm{CP}$ concentration of the green juice increases from $4.92 \mathrm{~g} / \mathrm{L}$ at $30^{\circ} \mathrm{C}$ to $12.52 \mathrm{~g} / \mathrm{L}$ at $50^{\circ} \mathrm{C}$ for an applied pressure of $500 \mathrm{kPa}$ (Table 2). The same tendency is observed for the highest applied pressure. 


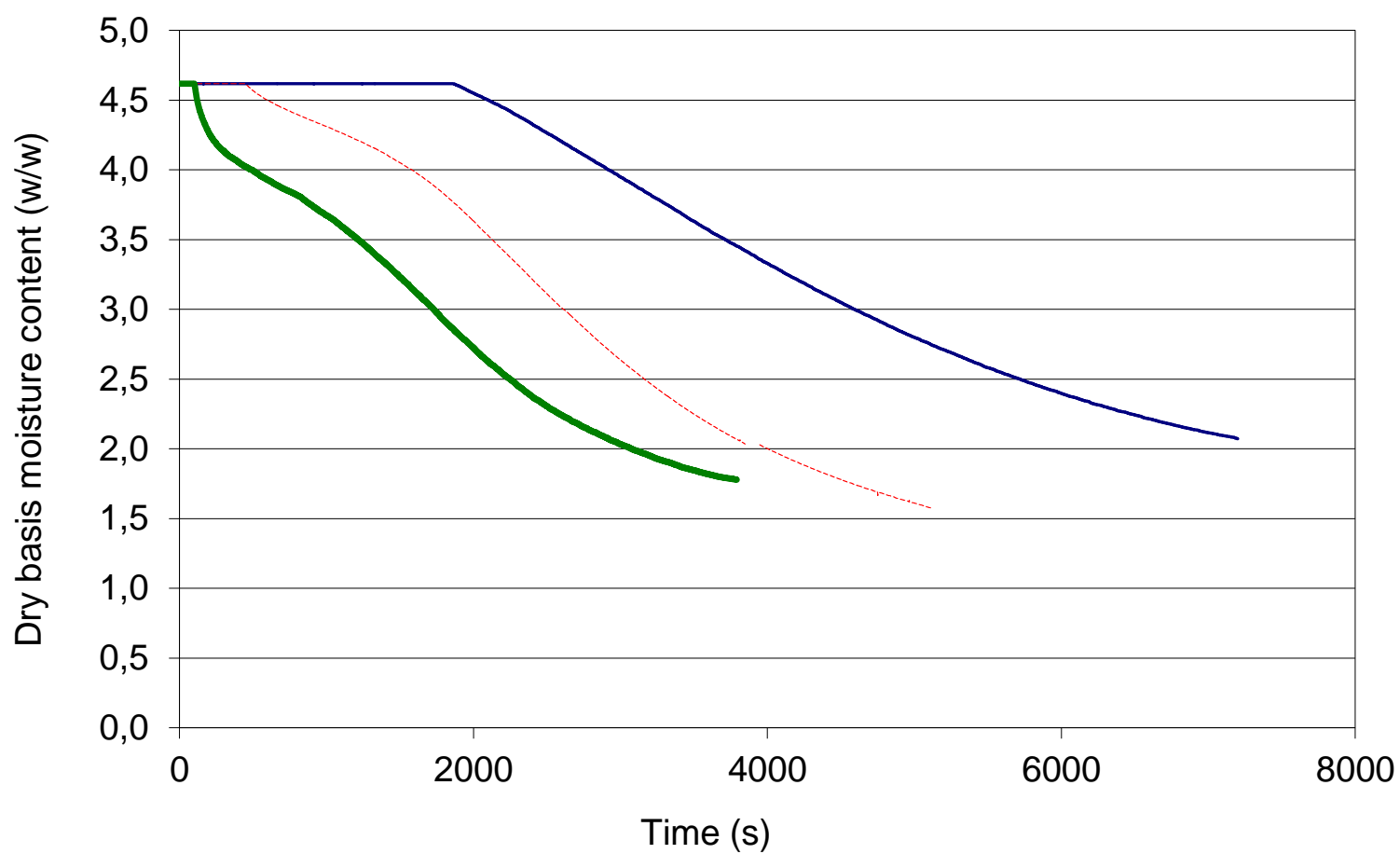

Figure 5 - Influence of the processing conditions on the dewatering kinetics for $\psi_{\mathrm{w}}=850 \mathrm{kPa}$ and $\mathrm{T}_{\text {wall }}=50^{\circ} \mathrm{C}$ and $\mathrm{P}_{\text {applied }}=300 \mathrm{kPa}(-), \mathrm{P}_{\text {applied }}=500 \mathrm{kPa}(--), \mathrm{P}_{\text {applied }}=1000 \mathrm{kPa}(-)$

Similar behaviors (see Figure 6) were observed with the two other batches sampled on June $15^{\text {th }}$ and $21^{\text {st }}$, respectively. For a wall temperature of $50^{\circ} \mathrm{C}$, a very short latency delay is observed during the dehydration of the sample of June $21^{\text {st }}$ when the applied pressure $\left(\mathrm{P}_{\text {applied }}=800 \mathrm{kPa}\right)$ exceeds slightly the biomass water potential $\left(\left|\psi_{\mathrm{w}}\right|=600 \pm 100 \mathrm{kPa}\right)$. At $70^{\circ} \mathrm{C}$, water runs immediately out of the press cake, even for a low applied pressure $\left(\mathrm{P}_{\text {applied }}=300 \mathrm{kPa}\right)$. Because of the weather conditions, the absolute value of the water potential of the second batch, sampled on June $15^{\text {th }}$, was appreciably lower $\left(\left|\psi_{\mathrm{w}}\right|=350 \pm 50\right.$ $\mathrm{kPa}$ ) than that of the two other batches. As soon as a pressure is applied, water is removed and the applied pressure has no influence on the dewatering kinetic. Finally, as already 
emphasized [37, 45], the amount of green juice recovered increases when the initial dry basis moisture content increases.

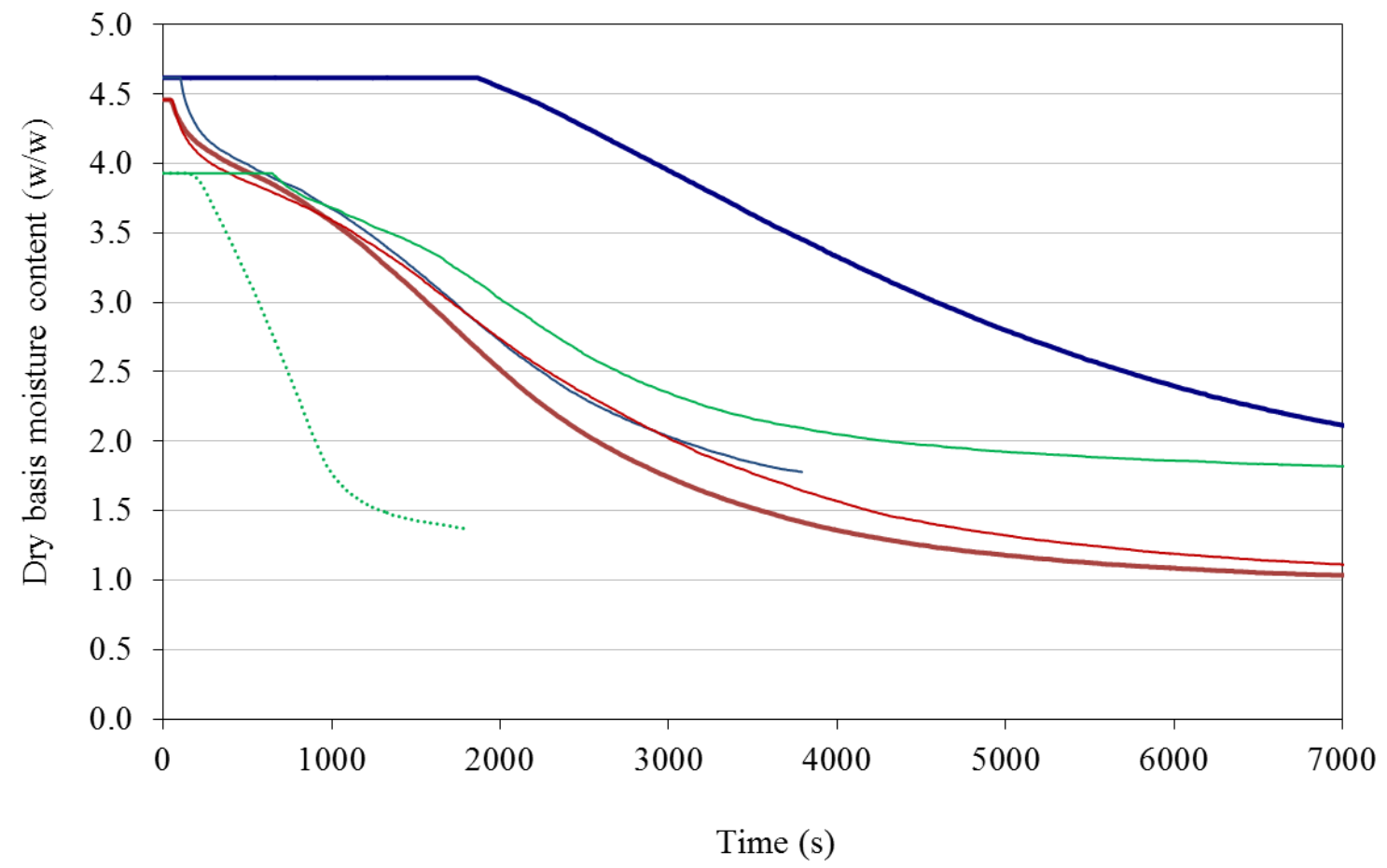

Figure 6 - Influence of the processing conditions and the water potential on the dewatering kinetics: $\psi_{\mathrm{w}}=850 \mathrm{kPa}, \mathrm{T}_{\text {wall }}=50^{\circ} \mathrm{C}$ and $\mathrm{P}_{\text {applied }}=300 \mathrm{kPa}(-), \psi_{\mathrm{w}}=850 \mathrm{kPa}, \mathrm{T}_{\text {wall }}=50^{\circ} \mathrm{C}$ and

$$
\begin{gathered}
\mathrm{P}_{\text {applied }}=1000 \mathrm{kPa}(-), \psi_{\mathrm{w}}=350 \mathrm{kPa}, \mathrm{T}_{\text {wall }}=50^{\circ} \mathrm{C} \text { and } \mathrm{P}_{\text {applied }}=300 \mathrm{kPa}(-), \psi_{\mathrm{w}}=350 \mathrm{kPa}, \\
\mathrm{T}_{\text {wall }}=50^{\circ} \mathrm{C} \text { and } \mathrm{P}_{\text {applied }}=500 \mathrm{kPa}(-), \psi_{\mathrm{w}}=600 \mathrm{kPa}, \mathrm{T}_{\text {wall }}=50^{\circ} \mathrm{C} \text { and } \mathrm{P}_{\text {applied }}=800 \mathrm{kPa}(-), \\
\psi_{\mathrm{w}}=600 \mathrm{kPa}, \mathrm{T}_{\text {wall }}=70^{\circ} \mathrm{C} \text { and } \mathrm{P}_{\text {applied }}=300 \mathrm{kPa}(\cdots \cdots) .
\end{gathered}
$$

The temperature has a positive influence both on the extraction kinetic and on the total amount of juice extracted, as expected from former results [37]. According to figures 3, 5 and 6 , the increase of the piston temperature significantly decreases the final biomass moisture content. The dry solid content of alfalfa sampled on June $8^{\text {th }}$ reaches $37.7 \%$ after processing at $50^{\circ} \mathrm{C}$ and hardly $21.5 \%$ at ambient temperature. Figure 7 presents the evolution of the extraction yield according to time for the alfalfa batch sampled on June $8^{\text {th }}$ and processing 
conditions that do not induce a latency time. Experiments highlight that the flow is immediate beyond $70^{\circ} \mathrm{C}$, whatever the pressure applied. The extraction yield is defined here as the ratio of the mass of green juice recovered to the mass of liquid intrinsically introduced with the raw biomass. Usually, it reaches $55 \%$ of the inherent liquid fraction available in the raw biomass. After $1 \mathrm{~h}$ of pressing, the extraction yield reaches $69 \%$, which represents an increase of $25.5 \%$ compared to current industrial processes. The enhancement is only of $11.8 \%$ at $50^{\circ} \mathrm{C}$. On the other hand, the $\mathrm{CP}$ content of the green juice produced with the wall temperature set to $70^{\circ} \mathrm{C}$ decreases probably because of the denaturation of soluble proteins and others substances which appears around $60-77^{\circ} \mathrm{C}[46]$.

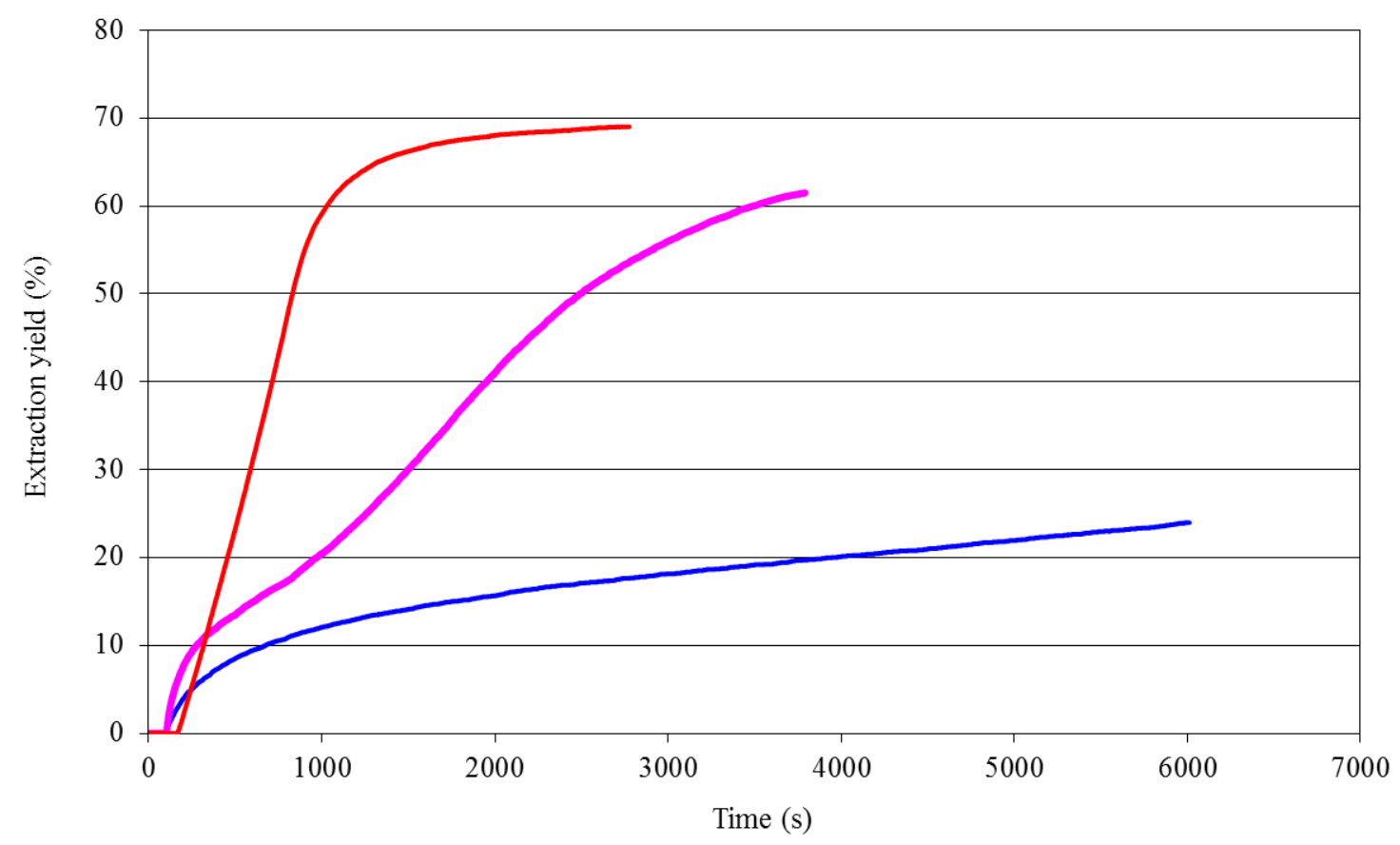

Figure 7 - Influence of the processing conditions on the dewatering yield for $\psi_{\mathrm{w}}=850 \mathrm{kPa}$ :

$\mathrm{T}_{\text {wall }}=30^{\circ} \mathrm{C}$ and $\mathrm{P}_{\text {applied }}=1000 \mathrm{kPa}(-), \mathrm{T}_{\text {wall }}=50^{\circ} \mathrm{C}$ and $\mathrm{P}_{\text {applied }}=1000 \mathrm{kPa}(-), \mathrm{T}_{\text {wall }}=70^{\circ} \mathrm{C}$ and $\mathrm{P}_{\text {applied }}=300 \mathrm{kPa}(-)$. 


\section{Conclusions}

High dewatering yield, $69 \%$ at $70^{\circ} \mathrm{C}$ and $61.5 \%$ at $50^{\circ} \mathrm{C}$, can be achieved through thermal intensification of mechanical dewatering. This study confirms that water potential succeeds as an indicator of the plant water status. At $70^{\circ} \mathrm{C}$, the juice flow is immediate, whatever the pressure applied. But, at lower wall temperature, the applied pressure must be adjusted to the water potential of the tissues to avoid a latency period before the juice flows out of the press cake. In the absence of any preliminary trituration of the biomass, the rise in temperature affects the permeability of the cell membrane, enhancing the CP content of the green juice. But if the temperature is too high, denaturation of soluble protein can occur and the CP concentration of the green juice decreases. To summarize, the TAMD process can operated in a conventional fodder drying facility as a pre-treatment for dewatering purpose. In the range of operating conditions investigated, $70^{\circ} \mathrm{C}$ and $300 \mathrm{kPa}$ are the optimum conditions to preserve the quality of the press cake and reach high separation yield $(+25.5 \%$ compared to the current process) in short times, reducing the inherent energy requirement for drying. The TAMD process can also be implemented for biorefining purpose. A lower wall temperature $\left(50^{\circ} \mathrm{C}\right.$ according to the present study) is required to improve the crude protein extraction. The major drawback is that the processing pressure should be adjusted to the water potential if the fodder is not sheared before pressing. Nevertheless, pressure chambers allow simple and fast measurements of the water potential even in the field environment. Knowing the optimal conditions for extraction (pressure, temperature and duration), the TAMD process scale-up is now considered. The objectives of the current work are to validate the proof of the concept in a continuous processing and to propose a mathematical model to predict heat and mass transfer in a thermally assisted mechanical dewatering process.

\section{Nomenclature}


CP

Crude protein content $(\mathrm{g} / \mathrm{L})$

$\mathrm{p}$

Protoplast (-)

$\mathrm{P}$

Pressure (kPa)

$\mathrm{T}$

Temperature $\left({ }^{\circ} \mathrm{C}\right)$

$\overline{\mathrm{V}}$

Partial molar volume $\left(\mathrm{m}^{3} / \mathrm{mol}\right)$

W

Dry basis moisture content $(\mathrm{kg} / \mathrm{kg})$

Greek symbol

$\psi$

Potential (kPa)

$\mu$

Chemical potential (kJ/mol)

Subscript

Gravity

gas

Gas

m

Matrix

$\mathrm{p}$

Pressure

S

Osmotic

W

Water

wall

Copper piston

0

Pure water 


\section{Acknowledgements}

This work has been supported by the French National Agency (ANR) in the frame of its Technological Research CP2D program (Produluz, project $n^{\circ}$ ANR-07-CP2D-16-02). The authors would like to acknowledge Bernard AUDUC for kind technical assistance in the construction and development of the experimental set-up.

\section{References}

[1] O'Keeffe, S.; Schulte, R.P.O.; Struik P.C. Alternative use of grassland biomass in Ireland: Grass for biorefinery. In Proceeding of the $15^{\text {th }}$ European Grassland Federation Symposium, Brno, Czech Republic, September 7-9, 2009; 297-313.

[2] Mandl, M.G. Status of green biorefining in Europe. Biofuel, Bioproducts and Biorefinery $2010,4,268-274$.

[3] Gastineau, I.; de Mathan, O. La préparation industrielle de la protéine verte de luzerne (Industrial processing of green alfalfa protein). In: Protéines Foliaires et Alimentation; Costes, C., Ed.; Gauthier-Villars : Paris, 1981; 159 -182.

[4] Koschuh, W.; Povoden, G.; Thang, V.H.; Kromus, S.; Kulbe, K.D.; Novalin, S. Production of leaf protein concentrate from ryegrass (Lolium perenne $\mathrm{x}$ multilroum) and alfalfa (Medicago sativa subsp. Sativa). Comparison between heat coagulation/centrifugation and ultrafiltration. Desalination 2004, 163, 253-259.

[5] Kamm, B.; Hille, C.; Schonicke, P.; Dautzenberg, G. Green biorefinery demonstration plant in Havelland (Germany). Bioproducts and Biorefinery 2010, 4, 253-262.

[6] Lei $\beta$, S.; Venus, J.; Kamm, B. Fermentative production of L-Lysine-L-lactate with fractionated press juices from the green biorefinery. Chemical Engineering\&Technology 2010, 33, 2102-2010. 
[7] Andersen, M.; Kiel, P. Integrated utilization of green biomass in the green biorefinery. Industrial Crops and Products 2000, 11, 129-137.

[8] Wachendorf, M.; Richter, F.; Fricke, T.; Graß, P.; Neff, R. Utilization of semi-natural grassland through integrated generation of solid fuel and biogas from biomass. Part I. Effect of hydrothermal conditioning and mechanical dehydration on mass flows of organic and mineral plant compounds, and nutrient balances. Grass and Forage Science 2009, 64, 132143.

[9] Walker, H.G.; Kohler, G.O.; Garrett, W.N. Comparative feeding value of alfalfa press cake residues after mechanical extraction of protein. Journal of Animal Science 1982, 55, 498-504.

[10] Koegel, R.G.; Strauss, R.J. Fractionation of alfalfa for food, feed, biomass and enzymes. Transactions of the ASAE 1996, 39, 769-774.

[11] Grass, S. Utilisation of grass for production of fibres, protein and energy; OECD Publication Service: Paris, 2004.

[12] Kromus, S.; Wachter, B.; Koschuh, W.; Mandl, M.; Krotscheck, C.; Narodoslawsky, M. The green biorefinery Austria - Development of an integrated system for green biomass utilization, Chemical and Biochemical Engineering Quarterly 2004, 18, 7-12.

[13] Sharma, H.S.S; Lyons, G.; McRoberts, C. Biorefining of perennial grasses: A potential sustainable option for Northen Ireland grassland production. Chemical Engineering Research and Design 2011, 89, 2309-2321.

[14] Keijsers, E.; Mandl, M. Green Biorefinery. http://www.bioref-integ.eu/fileadmin/biorefinteg/user/documents/8._Keijsers-_Green_Biorefinery_130910.pdf [accessed 15 July 2012]. [15] O’ Keeffe, S.; Schulte, R.P.O; Lalor, S.T.J.; O’Kiely, P.; Struik, P.C. Green biorefinery (GBR) scenarios for a two-cut sillage system: Investigating the impacts of sward botanical 
composition, $\mathrm{N}$ fertilization rate and biomass availability on GBR profitability and price offered to farmers. Biomass and Bioenergy 2011, 35, 4699-4711.

[16] Sinclair, S. Protein extraction from pasture. Literature Review Part A: The plant fractionation bio-process and adaptability to farming systems. http://www.maf.govt.nz/sff/about-projects/search/C08-001/literature-review.pdf [accessed 23 june 2012].

[17] Hanna, M.A.; Ogden, R.L. Expression of alfalfa juice. Journal of Agricultural and Food Chemistry 1980, 28, 1212-1216.

[18] Koschuh, W.; Kromus, S.; Krotscheck, C. Grüne Bioraffinerie - Gewinnung von Proteinen aus Grassäften. Bundesministeriums für Verkehr; Innovation und Technologie: Wien, 2003.

[19] Kamm, B.; Schönicke, P.; Kamm, M. Biorefining of green biomass - technical and energetic considerations. Clean 2009, 37, 27-30.

[20] Orsat, V.; Raghavan, G.S.V. ; Sotorinal, S.; Lightfoot, D.G.; Gopalakrishnan S. Roller press for electro-osmotic dewatering of bio-materials. Drying Technology 1999, 17, 523-538. [21] Gachovska, T.; Ngadi, M.O.; Raghavan, G.S.V. Pulsed electric field assisted juice extraction from alfalfa. Canadian Biosystem Engineering 2006, 48, 3.33-3.37.

[22] Sing, K. N.; Plunkett, A.; Stojceska, V., Ainsworth, P.; Lamont-Black, J.; Hall, J.; White, C.; Glendenning, S.; Russell D. Electro-kinetic technology as a low-cost method for dewatering food by-product. Drying Technology 2011, 29, 1721-1728.

[23] Tuan, P.A.; Mika, S.; Pirjo, I. Sewage Sludge Electro-Dewatering Treatment - A Review. Drying Technology 2012, 30, 691-706.

[24] Smythe, M.C.; Wakeman, R.J. The use of acoustic fields as a filtration and dewatering aid. Ultrasonics 2000, 38, 657-661. 
[25] Gallego-Juarez, J. A.; Rodriguez-Corral, G.; Gálvez Moraleda, J.C.; Yang T. S. A new high intensity ultrasonic technology for food dehydration. Drying Technology 1999, 17, 597608.

[26] Guo, J.; Hodges, S.; Uhlherr, P.H.T. Dewatering of HTD coal slurry by mechanical expression. Coal Preparation 1997, 18, 227-239.

[27] Strauss, K.; Berger, S.; Bergins, C. Mechanical thermal brown coal dewatering. In Proceedings of the XX International Mineral Processing Congress, Aachen, Germany, September 21-26 1997; 4, 75-82.

[28] Bergins, C.; Berger, S.; Strauss, K. Dewatering of fossil fuels and suspensions of ultrafine particles by mechanical thermal dewatering. Chemical Engineering and technology $1999,22,923-927$.

[29] Peuker, U.A.; Stahl, W. Steam pressure filtration: Mechanical thermal dewatering process. Drying Technology 2001, 19(5), 807-848.

[30] Clayton, S.A.; Scholes, O.N.; Hoadley A.F.A.; Wheeler, R.A.; McIntosh, M.J.; Huynh, D.Q. Dewatering of biomaterials by mechanical thermal expression. Drying Technology 2006, 24(7), 819-834.

[31] Lee, J.E. Thermal dewatering (TDW) to reduce the water content of sludge. Drying Technology 2006, 24(2), 225-232.

[32] Scholes, O.N. Mechanical thermal expression dewatering of lignite: direction dewatering and permeability characteristics. PhD Thesis, Melbourne, Australia, Department of Chemical Engineering, Monash University, 2005.

[33] Bergins, C. Kinetics and mechanism during mechanical/thermal dewatering of lignite. Fuel 2003, 82, 355-364.

[34] Clayton, S.A.; Wheeler, R.A.; Hoadley, A.F.A. Pore destruction resulting from mechanical thermal expression. Drying Technology 2007, 25, 533-546. 
[35] Fernandez, A.; Auduc, B.; Arlabosse, P.; Mahmoud, A. Method for mechanical dehydration with thermal assistance. European Patent 2212637, 2010.

[36] Mahmoud, A.; Arlabosse, P.; Fernandez, A. Application of a Thermally-Assisted Mechanical Dewatering Process to biomass. Biomass and Bioenergy 2011, 35, 288-297.

[37] Arlabosse, P.; Blanc, M., Kerfaï, S.; Fernandez, A. Production of green juice with an intensive thermo-mechanical fractionation process. Part 1: Effects of processing conditions on the dewatering kinetics. Chemical Engineering Journal 2011, 168, 586-592.

[38] Bergins, C.; Berger, S.; Strauss, K. Mechanical / Thermal dewatering - a perspective on an efficient solid / liquid separation. DKG 1999, 76, 8-12.

[39] Cusso Grau, N.; Blanc, M.; Arlabosse, P. Integration of a thermally assisted mechanical dewatering process in a drying facility. In Proceedings of the third European Drying Conference EuroDrying'2011, Palma de Majorque, Espagne, Octobre 26-28 2011.

[40] M. Blanc, P. Arlabosse, Thermo-mechanical fractionation of green biomass: optimisation of the processing conditions according to the water potential of the tissue. In Proceedings of the third European Drying Conference EuroDrying'2011, Palma de Majorque, Espagne, Octobre 26-28 2011.

[41] Yuegao, H.; Cash , D. Global status and development trends of Alfalfa. In: Alfalfa management guide for Ningxia TCP/CPR/3104; Cash, D., Ed.; United Nations Food and Agriculture Organization: Roma, 2009; 1-14.

[42] Kramer, P.J.; Boyer, J.S. Water relations of plants and soils; Academic Press Inc.: San Diego, 1995.

[43] Boyer, J.S. Measuring the water status of plants and soils; Academic Press Inc.: San Diego, 1995.

[44] Hopkins, W.G.; Huner, N.P. Introduction to Plant Physiology, $4^{\text {th }}$ edition; Wiley John \& Sons Inc.: New York, 2009. 
[45] Savoie, P.; Beauregard S. Predicting the effects of hay swath manipulation on field drying. Transactions of the ASAE 1990, 33, 1790-1794.

[46] Lamsal, B.P.; Koegel, R.G.; Gunasekaran, S. Some physicochemical and functional properties of alfalfa soluble leaf proteins. LWT Food Science Technology 2007, 40, 15201526. 